Caius College, Cambridge. After some work in geophysics and in the Meteorological Office he became assistant lecturer at Birmingham and was afterwards lecturer and head of the Department of Geography in the University of Durham from 1928 until 1939 , and was a University lecturer in the University of Cambridge from 1939 until 1948. He was president of the Royal Meteorological Society during 1945-46; and from 1955 until 1960 he served on the British National Committee for the International Geophysical Year. Much of his research in the field of meteorology and climate has been carried out in Lancashire, Westmorland and Cumberland and he has been increasingly concerned with problems of climatic fluctuations.

The Hill Farming Research Organization:

Dr. R. L. Reid

DR. R. L. REID, of the Commonwealth Scientific and Industrial Research Organization, Australia, has been appointed associate director and director designate of the Hill Farming Research Organization, 48 Palmerston Place, Edinburgh 12. It is expected that Dr. Reid will take up duties early in 1964 and that he will succeed $\mathrm{Mr}$. A. R. Wannop as director in about two years' time. Dr. Reid is a senior principal research officer in the Division of Animal Physiology at the Ian Clunies Ross Animal Research Laboratory at Prospect, New South Wales. He is a graduate of the Universitios of Sydney and Cambridge and in 1963 was awarded the Australian Medal of Agricultural Science. Throughout his research career, Dr. Reid has been concerned with sheep, and principally the physiology of nutrition, especially in pregnent ewes.

\section{The National Trust}

The sixty-eighth annual report of the National Trust, for the year 1962-63, reports that in spite of an increase in membership from 44,000 to 127,000 over the past decade, members' subscriptions still cover less than 10 per cent of the Trust's annual expenditure, and a large increase in subscription revenue is imperative if the Trust is to be in a position to seize new opportunities. At present, lack of money inhibits the work of the Trust at every turn. A public appeal is to be launched by the Trust in 1964 to save extensive areas of the coast-line. Of the 2,750 miles of coast-line in England, Wales and Northern Ireland, 1,900 are already beyond redemption, and there is constant pressure for development over the remainder. Trust ownership or protection by Trust covenants is the only permanent safeguard, and the new and immediate threats require immediate countering. In the past ten years, with the help of generous grants from the Ministry of Public Building and Works, made on the recommendation of the Historic Buildings Council, the Trust has been able to make systematic repairs to many of its historic houses, and in the past seven years $£ 860,000$ has also been spent on improvements of all kinds on the Trust's farms and estates. About $£ 560,000$ of this has come from sums received in legacies and donations during this period. The Trust was represented during the year at public enquiries held to consider proposals for tin prospecting at Zennor in Cornwall, for an overhead electricity line from Bolney to Lovedean in Sussex, and, unsuccessfully, for a radiocommunications tower at Goose Green in Gloucestershire.

\section{Scientific Research and the French Budget and Finance} Act

To the scientist the pamphlet The French Budget and Finance Act for 1963, obtainable by request from the Press and Information Department of the French Embassy, London, is remarkable for the absence of any information at all regarding expenditure on seience and technology either in research or development or in other ways (Pp. 20. London: Ambassade de France, Service de Presse et d'Information, 1963). The Finance Act is analysed from the point of view of the balance of revenue and expenditure and from that of the nature of the expenditure authorized. The latter analysis shows that defence expenditure has increased from 16,000 million francs in 1960 to 18,000 million in 1963; expenditure on education, culture and the arts from 8,700 million to 13,500 million; on health and social welfare from 5,900 million to 8,600 million; on agriculture from 2,500 million to 4,900 million; on mines and power from 3,300 to 4,400 million; on communications from 7,400 million to 10,500 million franes. The total expenditure in the same period rose from 73,100 to 95,000 million franes. A further pamphlet, Some Aspects of Scientific Research in France, to some extent rectifies this omission for 1962-63, as the Fourth Plan provides credits of 1,490 million franes for capital expenditure on civil research, of which 290 million is for new joint projects of technical research (Pp. 14. London: Ambassade de France, Service de Presse et d'Information, 1963). From this, 80 million francs should be deducted for telecommunications and 38 million for co-operation. Credits for present expenditure on research have tripled since 1959 and for capital expenditure are six times greater-the present figures for current expenditure representing an increase of 31 per cent and for capital expenditure of 40 per cent in 1962. Expenditure on the National Centre of Space Research or nuclear energy is in addition to the 1,490 million francs, but is not specified. In joint research projects, 111 million francs was expended in 1961-62, including 62 million francs for the Ministry of Education (15 million for the National Centre of Scientific Research and 31.5 million for universities). A credit of 41 million francs goes to oceanographic vessels and 59 million franes is earmarked in 1963 expenditure on water conservation. Comment is made on the reluctance of industry to apply new knowledge.

\section{Soviet Crude Oil Production: Some Statistics}

This is the title of one of a series of booklets dealing with industry in Communist countries issued in trans. lation into English by Joseph Crossfield and Sons, Ltd., Warrington, manufacturers of silicates, silica gels, catalysts, industrial detergents and other chemicals. In the present instance, the aim is to tabulate without comment such statistical data as have been collected on post-war crude oil production, processing and internal trade in the U.S.S.R. The sources of information are stated and are based exclusively on material published in the U.S.S.R. and other Communist countries. Much of this is in the original language. Editorial additions are restricted to brief comment where occasional inconsistencies occur within the sources themselves. The statistics given regarding Soviet oil cover summarily deposits and exploration, drilling, production of crude oil, production methods, productivity, capital investment, equipment, labour, costs and prices, raw materials and customers, consumption and transport. The data cover the essential oil-bearing regions of the U.S.S.R. and much of the information is normally difficult to obtain. Crossfield's say that this and similar booklets are "Published as a service to British industry ... freely available to all who are interested in them". Apart from modest and welldeserved advertisement, if this one booklet is an example of others previous and to be, then all concerned with contacts and trading with countries behind the Iron Curtain must be grateful for this enterprising departure from customary methods of circulating commercial intelligence.

\section{Publications of the Institute of Physics and the Physical Society}

BegINNINg with the January 1964 issue, the British Journal of Applied Physics will appear in a new format. The British Journal of Applied Physics is one of the three 